\title{
Curcumol Inhibit Breast Cancer Growth Via NCL/ERa36 And PI3K/AKT Pathway
}

\section{Zhou Lu Wei}

Guilin Medical University

Wang Juan

Guilin Medical University

Dou Tong

Guilin Medical University

Li Xiao Juan

Guilin Medical University

Liu Yi Sa

Guilin Medical University

Huang Fu Meng Jie

Guilin Medical University

Guan Xiao

Guilin Medical University

Liu Guo Xiang

Guilin Medical University

Han Meng Jie

Guilin Medical University

Chen Xu ( $\nabla$ chenxu@glmc.edu.cn)

Guilin Medical University https://orcid.org/0000-0003-0564-2021

\section{Research Article}

Keywords: Curcumol, Breast cancer, cycle arrest, ERa36, NCL,

Posted Date: December 8th, 2021

DOI: https://doi.org/10.21203/rs.3.rs-1110942/v1

License: (9) This work is licensed under a Creative Commons Attribution 4.0 International License.

Read Full License 
Curcumol Inhibit Breast Cancer Growth Via NCL/ER $\alpha 36$ and PI3K/AKT Pathway

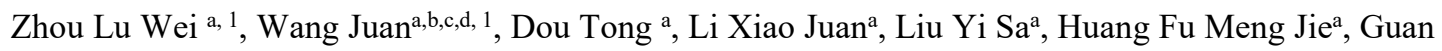
$\mathrm{Xiao}^{\mathrm{a}}$, Liu Guo Xiang ${ }^{\mathrm{a}}$, Han Meng Jie ${ }^{\mathrm{a}}, \quad$ Chen $\mathrm{Xu}^{\mathrm{a}, *}$

aDepartment of Pharmacy, Guilin Medical University, Guilin 541199, P.R. China

${ }^{b}$ Key Laboratory of Pharmacognosy, Education Department of Guangxi Zhuang Autonomous Region, 541199, P.R. China

${ }^{\mathrm{c} G u a n g x i}$ Key Laboratory of Molecular Medicine in Liver Injury and Repair, Guilin Medical University, 541001, P.R. China

${ }^{\mathrm{d} G u a n g x i}$ Health Commission Key Laboratory of Basic Research in Sphingolipid Metabolism Related Diseases, the Affiliated Hospital of Guilin Medical University, Guilin, 541001, Guangxi, China ${ }^{\mathrm{e}}$ Faculty of Basic Medicine, Guilin Medical University, No. 109, Guilin 541004, P.R. China

${ }^{1}$ These authors contributed equally to this work.

${ }^{*}$ Corresponding author

Xu Chen, Department of Pharmacy, Guilin Medical University, Zhiyuan Road, Lingui, Guilin, Guangxi Zhuang Autonomous Region 541199 P.R. China; Key Laboratory of Pharmacognosy, Guilin Medical University, 541199, P.R. China.

Tel: +86-773-5898018/ Fax: +86-773-5898018 Email: chenxu@glmc.edu.cn

\begin{abstract}
Purpose: This study is to investigate the effect and mechanism of curcumol on ER $\alpha 36$ positive breast cancer cells, and the relationship between curcumol's target protein nucleolin (NCL) and ER $\alpha 36$.

Methods: The anti-tumor effect of curcumol were quantified via MTT assay, colony formation and cycle arrest respectively. The expression of ER $\alpha 36, \mathrm{NCL}$ and the proteins involved in PI3K/AKT signaling were evaluated by western blotting. The interaction between two proteins were detected using co-immunoprecipitation (Co-IP) and immunofluorescence assay. Mouse xenograft model was
\end{abstract}


established to verify the role of ER $\alpha 36$ in breast cancer cells and curcumol's effect on ER $\alpha 36$ positive cancer cells.

Results: Curcumol inhibited the cell growth, caused cell cycle arrest, decreased cell cycle related-proteins and inactivated PI3K/AKT pathway in ER $\alpha 36$ positive breast cancer cells. There is a positive correlation between NCL and ER $\alpha 36$ in breast cancer cells. In addition, ER $\alpha 36$ bound to NCL, the two proteins were distributed in the nucleus, cytoplasm and on the plasma membrane, where their expression were obviously decreased by curcumol. Moreover, NCL silenced by NCL siRNA blocked the cell cycle progress and inhibited the activation of PI3K/AKT in MDA-MB-231 cells, while overexpressed ER 236 increased the expression of NCL, promoted cell cycle progress and enhanced the activity of PI3K/AKT in MCF-7 cells. NCL knockdown or ER 236 overexpressed all attenuated the effect of curcumol on breast cancer cells.

Conclusion: Curcumol reduced the proliferation of breast cancer cells by targeting NCL/ER $\alpha 36$ and inactivated PI3K/AKT pathway.

Keywords: Curcumol, Breast cancer, cycle arrest, ER $\alpha 36$, NCL, PI3K/AKT

\section{Introduction}

Breast cancer is the most common malignancy in women worldwide (https://www.who.int/publications/i/item/who-report-on-cancer-setting-priorities-investing-wisely-andproviding-care-for-all). Nearly $70 \%$ breast cancers express estrogen receptors(ERs)[1]. For ER-positive breast cancer, endocrine therapy is a common treatment for blocking estrogen signaling pathway[2]. Tamoxifen (TAM) is a classic ER-positive breast cancer treated drugs[3]. Unfortunately, it usually develops into TAM-resistance. For triple-negative breast cancer (TNBC), which always showed high metastasis, high invasiveness and poor prognosis[4]. There has no effective therapy for the lack of receptors expression. So, finding more effective therapeutic strategies for the treatment of drug-resistance and triple-negative breast cancer is urgent.

2005, Wang and his colleagues identified a ER $\alpha 66$ variant named ERa36[5], It is expressed in many breast cancer cells, especially highly expressed in TAM-resistant cell lines and triple-negative breast cancer[6]. Studies have shown that expression of ER $\alpha 36$ is related to the prognosis, metastasis and drug resistance of breast cancer[7, 8]. It also stimulates the activation of PI3K/AKT and MAPK/ERK pathway[9]. More and more researches showed that ER $\alpha 36$ is a novel biomarker to 
overcome drug resistance and enhance the effectivity of triple negative breast cancer[10]. Therefore, novel and effective agents target of ER $\alpha 36$ are urgently needed.

Curcumol, an effective ingredient extracted from the volatile oil of traditional Chinese medicine Curcuma zedoaria (Christm.) Rosc. Studies have shown that curcumol can inhibit cell proliferation of various cancers [11-15]. For breast cancer, curcumol can induce cell apoptosis by inhibiting cancer cell metastasis and epithelial-mesenchymal transition, induce cell cycle arrest and act as an adjuvant therapy to increase the sensitivity of cells to drugs[15]. In our previous experiment, we found that NCL is a protein target of curcumol[16]. NCL is associated with poor prognosis in multitudinous cancer, it affects DNA repair, cell survival, angiogenesis, epithelial-mesenchymal transition and stemness[17]. And anti-NCL is a promising strategy for the treatment of breast cancer[18]. Recently, we found that ERa36 and NCL could interact with each other, so we want to explore whether curcumol inhibits breast cancer growth is related with the expression of NCL and ER $\alpha 36$, and whether the PI3K/AKT pathway is involved in the anti-breast cancer effect of curcumol.

\section{Materials and Methods}

1. Reagents

Curcumol (purity $>98 \%$ ) was purchased from Guizhou Dida Technology Co., Ltd (Guizhou, China). 3-(4,5-dimethylthiazol- 2-yl)-2,5-diphenyl-tetrazolium bromide (MTT) were purchased from Amresco, LLC (Solon, OH, USA). DMSO were purchased from Sigma-Aldrich (St. Louis, MO, USA). Anti-rabbit IgG, anti-mouse IgG and antibodies against $\beta$-actin were purchased from ZSGB-BIO (Beijing, China). The anti-PI3 Kinase P110 $\beta$, anti-PI3 Kinase P85 $\alpha$, anti-Nucleolin, anti-AKT, anti-phosphor(p)-AKT, anti-PARP-1, anti-P53, anti-Bcl-2 were purchased from Abcam (Cambridge, MA, USA), anti-CDK6, anti-CyclinD1, anti-CDK2 were purchased from Cell Signaling Technology (Danvers, MA, USA), anti-PCNA, anti-P21 were purchased from Wanleibio, LLC (Shenyang, China), anti-ER $\alpha 36$ antibody and plasmid vector were provided by Zhao Yi Wang (Creighton University Medical School).

2. Cell culture and treatment

The breast cancer cell lines MCF-7, MDA-MB-231 and the human normal breast epithelial cell MCF10A were purchased from Shanghai Cell Bank, Conservation Genetics, the Chinese Academy of Sciences(shanghai, China). The TAM-resistant cell lines (MCF-7 TAM-R) were provided with Dr ZY Wang. All cells were cultured in Dulbecco's modified Eagle's medium (Gibco, Grand Island, NY, 
USA) with 10\% FBS (Gibco, Auckland, New Zealand), $100 \mathrm{U} / \mathrm{mL}$ penicillin and $100 \mu \mathrm{g} / \mathrm{mL}$ streptomycin at $37^{\circ} \mathrm{C}$ in a $5 \% \mathrm{CO}_{2}$ incubator. In addition, MCF-7 TAM-R incubated in medium containing $1 \mu \mathrm{M}$ TAM to maintain resistance. MCF10A was cultured with Mammary Epithelial Cell Growth Medium (Lonza/Clonetics, Basel, Switzerland). The cells were pre-treated with different concentrations of curcumol $(0,12.5,25,50,100 \mu \mathrm{g} / \mathrm{mL})$. All cells are in the logarithmic growth phase for experiments.

3. Cell viability assay

Cells were seeded in 96-well plates at $3 \times 10^{3}$ per well. And then treated with curcumol at indicated concentrations for $24 \mathrm{~h}, 48 \mathrm{~h}, 72 \mathrm{~h}$. Then $20 \mu \mathrm{L} 5 \mathrm{~g} / \mathrm{L}$ MTT solution was added to each well and cells continued to incubate for $4 \mathrm{~h}$ at $37^{\circ} \mathrm{C}$. Subsequently, the supernatant was removed and $150 \mu \mathrm{L}$ DMSO was added to dissolve the formed formazan crystals, then measured the absorbance at $490 \mathrm{~nm}$ wavelength using a microplate reader (TECAN, Männedorf, Switzerland) and calculated the cell proliferation inhibition rate.

4. Cell colony forming assay

Eight hundred cells were seeded into 6-well plates and treated with curcumol. The medium was replaced with fresh medium every 3-4 days. After 12 days, the colonies were fixed with anhydrous methanol for $15 \mathrm{~min}$ and stained with Giemsa Reagen (solarbio, Beijing, China) at $25^{\circ} \mathrm{C}$ for $30 \mathrm{~min}$. The images of the stained cells were taken using the Gel System Imaging System (Bio-Rad, Hercules, CA, USA).

5. Cycle arrest analysis by flow cytometry

Cells were collected after treating with curcumol for $48 \mathrm{~h}$, washed twice with ice-cold PBS and immobilized with ice-cold $80 \%$ ethanol at $-20^{\circ} \mathrm{C}$. The next day, the supernatant was discarded after centrifuging at $1500 \mathrm{rpm}$ for $10 \mathrm{~min}$, then the cells were washed twice with ice PBS, incubated with RNase $(100 \mu \mathrm{g} / \mathrm{mL})$ at $37^{\circ} \mathrm{C}$ for $30 \mathrm{~min}$. Afterwards, the cells were stained with propidium iodide (50 $\mu \mathrm{g} / \mathrm{mL}$ ) at $25^{\circ} \mathrm{C}$ for $30 \mathrm{~min}$ in the dark. The cells were tested by flow cytometry (Becton Dickinson, San Jose, CA, USA).

6. Western blot analysis

Cells were seeded in 100-mm Petri dishes and treated with curcumol for $48 \mathrm{~h}$. cells were collected and lysed with RIPA buffer for $30 \mathrm{~min}$ on ice, the lysates were centrifuged at $4^{\circ} \mathrm{C}, 12000 \mathrm{rpm}$ for 20 
min, the protein concentrations were measured with BCA protein assay kit. Then protein was isolated by SDS/PAGE electrophoresis and transferred to the nitrocellulose membranes, these membranes were blocked with 5\% skim milk for $2 \mathrm{~h}$ and washed three times with PBST for 10 min each time. Then incubated with indicated specific primary antibodies for overnight at $4{ }^{\circ} \mathrm{C}$. The next day, the membranes were washed three times with PBST for 10 min each time and incubated with HRP-conjugated goat anti-rabbit or anti-mouse $\operatorname{IgG}$ for $1 \mathrm{~h}$ at $25^{\circ} \mathrm{C}$. Finally, the membranes were detected using western blot imaging system (Bio-Rad, Hercules, CA, USA).

7. Co-Immunoprecipitation (Co-IP) analysis

Protein A/G Magnetic Beads were incubated with anti-NCL antibody or IgG for overnight at $4{ }^{\circ} \mathrm{C}$. Beads were resuspended in the wash buffer and incubated with the supernatant which were aspirated from cell lysis solution for $3 \mathrm{~h}$ in $4^{\circ} \mathrm{C}$. Then, the beads were eluted with eluent buffer $(0.1 \%$ SDS, $1 \%$ Triton $\times 100,50 \mathrm{mM}$ Tris- $\mathrm{HCl}(\mathrm{pH} 8.0), 150 \mathrm{mM} \mathrm{NaCl}, 10 \%$ glycerol. Subsequently using anti-ER $\alpha 36$ antibody as probe to detect the expression of ER $\alpha 36$ on SDS- polyacrylamide gel electrophoresis.

8. Immunofluorescence assay

Cells were treated with curcumol for $48 \mathrm{~h}$, cells fixed with $4 \%$ paraformaldehyde for $15 \mathrm{~min}$, and then permeabilized with $0.1 \%$ Triton $\mathrm{X}-100$ at $25^{\circ} \mathrm{C}$ for $10 \mathrm{~min}$, then cells were blocked with $5 \% \mathrm{BSA}$ and incubated with primary antibody overnight. Next day cells were blocked with 5\% BSA again and incubated with another primary antibody overnight at $4{ }^{\circ} \mathrm{C}$. Next day, the cells were incubated with two secondary antibodies for 2 hours at $25^{\circ} \mathrm{C}$, then cells were added into DAPI $(0.1 \mu \mathrm{g} / \mathrm{mL}$, Abcam) which was used to visualize the cell nuclei. The samples were observed with laser scanning confocal microscope (OLYMPUS OPTICAL CO., LTD, Japan).

\section{Si-RNA assay}

The NCL siRNA and universal negative control siRNA were synthesized by BIOLIGO Biotechnologies (Shanghai, China). The sequences are shown in the appendix. MDA-MB-231 cells were seeded in 6-well plates. Then NCL siRNA and control siRNA were transfected into cells with Lipofectamine ${ }^{\mathrm{TM}} 3000$ Reagent following the manufacturer's instructions. Subsequently, the cells were treated with or without $50 \mu \mathrm{g} / \mathrm{mL}$ curcumol for $48 \mathrm{~h}$. Then we detected cell arrest using flow cytometry or relative factors by western blotting.

10. The establishment of ER $\alpha 36$ stable over-expression cells 
Lentiviral particles were produced in $293 \mathrm{~T}$ cells by co-transfecting the lentiviral construct and plasmid pCDH-CopGFP-puro. Plasmids (pCDH-CopGFP-puro-ER $\alpha 36$ and pCDH-CopGFP-puro) were generously provided by Zhaoyi Wang. MCF-7 cells were transfected with plasmids and $5 \mu \mathrm{g} / \mathrm{mL}$ polybrene in six-well plates. After 8 h, DMEM medium containing 10\% FBS was replaced. At 48 h, 5 $\mu \mathrm{g} / \mathrm{mL}$ Puromycin was used to stable clone selection.

\section{Animal experiments}

Four-weeks-old female nude mice were purchased from SJA Experimental Animal Co., Ltd. (Changsha, Hunan). All animals were randomly divided into two groups. Every mouse was inoculated $1 \times 10^{7}$ cells suspending in $0.2 \mathrm{~mL}$ PBS. The cell MCF-7 ER $\alpha 36$ and MCF-7 NC were respectively injected into the flank of the mice. When tumor volume reached $100 \mathrm{~mm}^{3}$, the mice were randomly assigned to control group or experimental group. The experimental group received intragastric administration of $80 \mathrm{mg} / \mathrm{kg}$ curcumol every day for 3 weeks, control group treated with solvent. The growth of tumor was monitored every 3 days. Then, animals were sacrificed, the xenograft tumors were harvested. the volume of tumors was calculated according to the formula: volume $=$ width $^{2} \times$ length $\times 1 / 2$.

12. Statistical analysis

The data were analyzed by SPSS version 21.0(SPSS, Inc.), All results were presented as the mean \pm standard deviation (SD). Student's t-test and one-way ANOVA were conducted to analyze the statistical significance between different groups. $\mathrm{P}<0.05$ was considered statistically significant.

\section{Results}

\section{Curcumol inhibits breast cancer cells proliferation}

As shown in Figure 1 a, MCF-7 and MCF-7 TAM-R were treated with 5, $10 \mu \mathrm{M}$ TAM simultaneously, the viability of MCF-7 cells was decreased, while the cell viability was increased in MCF-7 TAM-R cells. Our data showed that MCF-7 TAM-R really resistance to TAM. As shown in Figure $1 \mathrm{c}$, curcumol inhibited the growth of ER $\alpha$-positive cells MCF-7, triple-negative breast cancers MDA-MB-231 and tamoxifen-resistant cells MCF-7 TAM-R in a concentration and time-dependent manner. In addition, to detect the cell toxicity of curcumol on normal human breast cells, we analyzed the cell growth of MCF10A after curcumol treated, the results demonstrated that there was a slight growth-promoting effect of curcumol (Figure 1c). 
The cell cycle distribution of curcumol intervention were examined by flow cytometry. As presented in Fig 2, MCF-7, MDA-MB-231 and MCF-7 TAM-R cells treated by curcumol were caused G1 phase arrest. Western blotting showed that cell cycle regulatory genes CDK6, CDK2, Cyclin D1 were significantly decreased by curcumol in a dose-dependent manner in cells. In MCF-7 TAM-R cells, curcumol regulated additionally the expression of P53 and P21, which two factors were also related to G1 phase arrest.

\section{Curcumol inhibits the growth of breast cancer cells by regulating the PI3K/AKT pathway}

Given both of the drug resistance development in breast cancer and the anti-tumor effect of curcumol were associated with PI3K/AKT $[19,20]$. We detected whether curcumol's cell cycle arrest effect was related with the inhibition of PI3K/AKT pathway. Our results revealed that curcumol reduced the protein levels of P110, P85 and P-AKT/AKT in MCF-7, MDA-MB-231 and MCF-7 TAM-R cells (Figure 3). Taken together, these results demonstrated that curcumol inhibited the activation of the PI3K/AKT pathway, thereby inhibited the cell cycle progress.

\section{Curcumol inhibited the expression of ER $\mathrm{E} 36$ was related with its protein target NCL}

As a high-malignant biomarker, NCL is highly expressed in breast cancer and is closely related to poor prognosis. Our research group have shown that the anti-cancer target of curcumol in nasopharyngeal carcinoma is NCL. So, the expression of NCL in breast cancer form The Cancer Genome Atlas (TCGA) was acquired and analyzed using xiantao Browser (https://www.xiantao.love), then found that the level of NCL was significantly higher in 1109 breast cancer tissues than 113 normal tissues ( $p<0.001$; Figure $4 \mathrm{~d}$ ). we found the expression of ER $\alpha 36$ was consistent with the expression of NCL in breast cancer cells (Figure 4 a,b,c). We further investigated the interaction of NCL with ER $\alpha 36$ by immunoprecipitation, and the two proteins could be co-precipitated as shown in fig 4 e. Then, we verified that the effect of curcumol on breast cancer cells were associated with ER $\alpha 36$ and NCL. As shown in Figure 4a-c, curcumol decreased the expression of NCL and ER $\alpha 36$ in three breast cancer cell lines. And dual-immunofluorescence staining showed that NCL and ER $\alpha 36$ co-localized in MCF-7 TAM-R cells and the two proteins expression in cell membrane were decreased under curcumol's treatment (Figure 4f).

NCL SiRNA reduce curcumol's inhibition on cell cycle arrest, ER- $\alpha 36$ expression and PI3K/AKT activation 
Then we silenced NCL in MDA-MB-231 cells. As shown in fig5 a and b, we harvested si-RNA for NCL in MDA-MB-231 cells, we found that the expression of ER $\alpha 36$ was decreased along with NCL's silenced. As shown in fig5 c, the cell percentage of G1 phase was significantly increased in curcumol and NCL siRNA single treated group, compared with control group. However, there was no obvious change in the NCL siRNA and curcumol co-treated group compared with NCL siRNA single treated group. So, the effect of curcumol on the cell cycle was reduced significantly after NCL silenced. In addition, the effect of curcumol on the expression of ER $236, \mathrm{P} 110, \mathrm{P} 85, \mathrm{P}-\mathrm{AKT}, \mathrm{CDK} 6, \mathrm{Cyclin} \mathrm{D} 1$, and PCNA was significantly weakened when NCL was inhibited (Figure $5 \mathrm{~d}$ ). NCL down-regulation suppressed activation of ER $\alpha 36$ and PI3K/AKT pathway and cell cycle associated factors.

\section{ERa36 overexpression attenuated the inhibitory effect of curcumol}

In order to reveal the effect of ER $\alpha 36$ on curcumol's anti-cancer activity, then we constructed MCF-7 cell line with stable overexpressed ER $\alpha 36$. The results showed that when ER $\alpha 36$ was over-expressed, the expression of NCL was also up-regulated. Meanwhile, the expression of them were all decreased under curcumol's intervention (Figure 6 b). Compared with MCF-7, ER $\alpha 36$ overexpressed reduced the proportion of G1 phase and promoted the cell cycle progress $(52.6 \% \mathrm{vs}$ 35.4\%). And the cell cycle arrest effect of curcumol was inhibited in the MCF-7 ER $\alpha 36-L V$ cells compared with MCF-7 cells (Figure 6 c). Mechanistically, the expression of P110, P85, P-AKT, Cyclin D1, PCNA, CDK6 and CDK2 were slightly up-regulated in ER 236 over expressed MCF-7 cells and the effect of curcumol on them was also inhibited when ER $\alpha 36$ was over expressed (Figure $6 \mathrm{~d}$ ).

\section{Curcumol inhibition on tumor growth was reversed by ERa36 in vivo}

In order to investigate whether the expression of ER $\alpha 36$ affects curcumol's inhibition on the growth of breast cancer cells in vivo, we orthotopically grafted MCF-7 and MCF-7 ER $\alpha 36-L V$ cell lines. As figure 7 a-c showed that ER $\alpha 36$ markedly increased the tumor growth of MCF-7 cells in vivo. Curcumol obviously inhibited the proliferation of breast cancer whether ER $\alpha 36$ overexpressed or not. However, compared with MCF-7 NC, the inhibitory effect of curcumol on tumor growth was sightly attenuated when ER $\alpha 36$ overexpression (Figure $7 \mathrm{c}$ ). And the body weight of nude mice showed no obviously difference between MCF-7 NC and MCF-7 ER $\alpha 36$ group (Figure 7 d). In addition, ER $\alpha 36$ expression in MCF-7 ER $\alpha 36$ xenograft tissues were markedly higher than in MCF-7 NC tissues, and curcumol's treatment decreased the expression of ER $\alpha 36$ more obviously in control than in ER $\alpha 36$ overexpressed tissues (Figure 7 e). Besides ER 236 , the expression of NCL, P110, P85, P-AKT, PCNA, 
CDKS, Cyclin D1 were down-regulated not so remarkably in ER $\alpha 36$ overexpressed than in control group. These results suggested that curcumol still has anti-cancer effect on malignant tumors with high expression of ER $\alpha 36$, but ER $\alpha 36$ slightly reduce curcumol's sensitivity in vivo.

\section{Discussion}

In recent years, tamoxifen resistance presents a great clinical challenge for the ER-positive breast cancer therapy. Though there has been developed a number of regimens with single or comprehensive agents for the treatment of TNBC, few of them is satisfied and most of the clinical results is also disappointed[21]. So, identifying specific targets and developing more effective therapies for tamoxifen resistance and TNBC patients is urgent.

Accumulating evidence has demonstrated that ER $\alpha 36$ was related with tamoxifen resistance and poor prognosis[22], it promoted cisplatin resistance through nongenomic estrogen signaling[23] and promoted cancer cells metastasis[24]. And down-regulated its expression reduced the migration and invasion of MDA-MB-231 cells[25-27]. Recently, Guangliang Li found that ER $\alpha 36$ overexpressed was shown to be a potential mechanism for tamoxifen resistance generation. Additionally, ER $\alpha 36$ plays a critical role in the development of TNBC[28]. So, ER $\alpha 36$ has been proposed to be a candidate therapeutic target for the treatment of TNBC and tamoxifen resistance breast cancer[19, 28]. Some natural drugs such as icaritin[28], EGCG[29] and Huaier polysaccharide[21] have been demonstrated to be potential therapeutic agents for ER $\alpha 36$ positive breast cancer. Curcumol, a major sesquiterpenoid compound isolated from Rhizoma zedoariae, also demonstrated obvious inhibition effect on TNBC[30].

Our team member Juan Wang found that NCL is a protein target of curcumol in nasopharyngeal carcinoma cells[16]. It is high expressed most cancer cells and closely related with tumor tumorigenesis, migration and invasion[31, 32]. So, NCL is a potential target for anticancer[33, 34]. In this study, we found that curcumol caused proliferation inhibition and cell cycle arrested in MCF-7 TAM-R and MDA-MB-231 cells. Meanwhile, curcumol inhibited the expression of NCL and ER $\alpha 36$, and the two factors interacted with each other. Meanwhile, NCL and ER $\alpha 36$ were co-located in the nucleus of MCF-7 TAM-R cells after cucumol treated. In order to further study the relationship between NCL and ER $\alpha 36$, we silenced the expression of NCL by siRNA and over-expressed ER $\alpha 36$ by lentiviral transfection, and found that blocking NCL expression decreased the expression of ER $\alpha 36$, and ER $\alpha 36$ increased the expression of NCL. Silencing of the target gene of NCL attenuated the anti-cancer effect of the curcumol. 
It has been confirmed that the PI3K/AKT pathway plays an important role in estrogen receptor negative and breast cancer resistance therapy[35], its activation is associated with endocrine resistance and worse prognosis in breast cancer patients[36]. Our previous studies have revealed that curcumol induced MDA-MB-231 cells apoptosis in vitro and vivo[30]. Meanwhile, other researchers found that curcumol act as a sensitizer to improve doxorubicin's effect [37]. ER $\alpha 36$ high expressed is the common characteristic for TNBC and tamoxifen-resistance breast cancer. So, we focus on the effect of curcumol on the expression of ER $\alpha 36$ and its relationship with PI3K/AKT pathway. In the present study, over-expressed of ER $\alpha 36$ increased the expression of NCL and promote cell cycle progress. In addition, high expressed of ER $\alpha 36$ leaded to the expression of carcinogenic driver CDKS increased and stimulated the activation of PI3K/AKT. Moreover, ER $\alpha 36$ overexpression sightly attenuated the inhibition effect of curcumol on breast cancer cells in vitro and vivo. However, the effect of curcumol on the interaction of NCL and ER $\alpha 36$, and the mechanism of how NCL siRNA and ER $\alpha 36$ overexpressed affected the effect of curcumol on breast cancer need further study.

In conclusion, our current study revealed that curcumol inhibited cell growth and induced cell cycle arrest in ER 236 positive breast cancer. And the effect of curcumol on breast cancer is closely related with the expression of NCL and ER $\alpha 36$, and the activation of PI3K/AKT pathway. Fully understanding of the roles of traditional Chinese herbal medicines in tumor progression may provide a new perspective for the development of novel cancer treatment strategies.

Acknowledgments and Funding Information: This work was supported by the National Natural Science Foundation of China (grant\# 81760443, 81760663, 82160768 and 82002822), the Project of Guangxi Special Fund Project for Innovation-Driven Development (grant\# GuikeAA19254025), Guangxi Science and Technology and Talents Special Project (grant no. 2019AC19009), Guangxi Natural Science Foundation (grant\# Guike ZD20302006). Sincerely thanks to professor Zhaoyi Wang generously provided us MCF-7 TAM cells, ER $\alpha 36$ antibody and ER $\alpha 36$ plasmids.

\section{References}

1. Traboulsi T, Ezzy ME, Gleason J, Mader S: Antiestrogens: structure-activity relationships and use in breast cancer treatment. Journal of Molecular Endocrinology 2016, 58(1):R15-R31.https://doi.org/ 10.1530/JME-16-0024

2. Selli C, Dixon JM, Sims AH: Accurate prediction of response to endocrine therapy in breast 
cancer patients: current and future biomarkers. Breast Cancer Research 2016, 18(1):1-10. https: //doi.org/10.1186/s13058-016-0779-0

3. Mcandrew NPF, R. S.: Management of ER positive metastatic breast cancer. Seminars in Oncology 2020, 47(5):270-277.https://doi.org/10.1053/j.seminoncol.2020.07.005

4. Yin L, Duan J, Bian XW, Yu SC: Triple-negative breast cancer molecular subtyping and treatment progress. Breast cancer research 2020, 22(1):61. https://doi.org/ 10.1186/s13058-020-01296-5

5. Wang Z, Zhang X, Shen P, Loggie BW, Deuel TF: Identification, cloning, and expression of human estrogen receptor-alpha36, a novel variant of human estrogen receptor-alpha66. Biochemical Biophysical Research Communications 2005, 336(4):1023-1027.https: //doi.org/ 10.1016/j.bbrc.2005.08.226

6. Gu W, Dong N, Peng W, Shi C, Yang J, Jian W: Tamoxifen resistance and metastasis of human breast cancer cells were mediated by the membrane-associated estrogen receptor ER- $\alpha 36$ signaling in vitro. Cell Biology Toxicology 2017, 33(2):183-195.https://doi.org/10.1007/ s10565-016-9365-6

7. Burness ML, Wicha MS: Tamoxifen and ERa36: Fertilizing the seeds of breast cancer metastasis. Cell Research 2018, 28(4):391-392. https://doi.org/ 10.1038/s 41422-018-0028-4

8. Wang $Q$, Jiang J, Ying G, Xie XQ, Zhang X, Xu W, Zhang X, Song E, Bu H, Ping YF: Tamoxifen enhances stemness and promotes metastasis of ERa36+ breast cancer by upregulating ALDH1A1 in cancer cells. Cell Research 2018, 28(3):336-358.https://doi.org/ 10.1038/cr.2018.15

9. Zhang XT, Ding L, Kang LG, Wang ZY: Estrogen Receptor- $\alpha 36$ Mediates Mitogenic Antiestrogen Signaling in ER-Negative Breast Cancer Cells. PloS one 2012, 7(1):e30174. https://doi.org/ 10.1371/journal.pone.0030174

10. Su X, Xin X, Li G, Lin B, Teng L: ER- $\alpha 36$ : a novel biomarker and potential therapeutic target in breast cancer. OncoTargets and therapy 2014, 7:1525-1533.https://doi.org/ 10.2147/OTT.S65345

11. Wang J, Li XM, Bai Z, Chi BX, Wei Y, Chen X: Curcumol Induces Cell Cycle Arrest in Colon Cancer Cells via Reactive Oxygen Species and Akt/ GSK3ß/cyclin D1 Pathway. Journal of ethnopharmacology 2018, 210:1-9. https://doi.org/ 10.1016/j.jep.2017.06.037

12. Wang J, Li XM, Bai Z, Chi BX, Wei Y, Chen X: Curcumol Induces Cell Cycle Arrest in Colon Cancer Cells via Reactive Oxygen Species and Akt/ GSK3ß/cyclin D1 Pathway. Journal of ethnopharmacology 2017, 210:1-9. https: //doi.org/ 10.1016/j.jep.2017.06.037

13. Li X LH, Wang J, Qin J, Bai Z, Chi B, Yan W, Chen X. : Curcumol induces cell cycle arrest and apoptosis by inhibiting IGF-1R/PI3K/Akt signaling pathway in human nasopharyngeal carcinoma CNE-2 cells. Phytotherapy Research 2018, 32(11):2214-2225. https://doi.org/ 10.1002/ptr.6158

14. Yu D, Liu H, Qin J, Huangfu M, Guan X, Li X, Zhou L, Dou T, Liu Y, Wang L: Curcumol inhibits the viability and invasion of colorectal cancer cells via miR30a5p and Hippo signaling pathway. Oncology Letters 2021, 21(4):299. https://doi.org/ 10.3892/ol.2021.12560

15. Huang L, Li A, Liao G, Yang F, Yang J, Chen X, Jiang X: Curcumol triggers apoptosis of p53 mutant triple-negative human breast cancer MDA-MB 231 cells via activation of p73 and PUMA. Oncology Letters 2017, 14(1):1080-1088.https://doi.org/ 10.3892/ol.2017.6273 
16. Wang J, Wu J, Li X, Liu H, Qin J, Bai Z, Chi B, Chen X: Identification and validation nucleolin as a target of curcumol in nasopharyngeal carcinoma cells. Journal of Proteomics 2018, 182:1-11. https://doi.org/ 10.1016/j.jprot.2018.04.025

17. Ugrinova I, Petrova M, Chalabi-Dchar M, Bouvet P: Multifaceted Nucleolin Protein and Its Molecular Partners in Oncogenesis. Advances in Protein Chemistry Structural Biology 2017, 111:133-164. https://doi.org/ 10.1016/bs.apcsb.2017.08.001

18. Bourdon JC PD, Bouvet P, Diaz JJ, Marcel V. : Druggable Nucleolin Identifies Breast Tumours Associated with Poor Prognosis That Exhibit Different Biological Processes Cancers 2018, 10(10):390. https://doi.org/ 10.3390/cancers10100390

19. Li G, Zhang J, Xu Z, Li Z: ERalpha36 as a Potential Therapeutic Target for Tamoxifen-Resistant Breast Cancer Cell Line Through EGFR/ERK Signaling Pathway. Cancer Manag Res 2020, 12:265-275.https://doi.org/ 10.2147/CMAR.S226410

20. Li X, Liu H, Wang J, Qin J, Bai Z, Chi B, Yan W, Chen X: Curcumol induces cell cycle arrest and apoptosis by inhibiting IGF-1R/PI3K/Akt signaling pathway in human nasopharyngeal carcinoma CNE-2 cells. Phytother Res 2018, 32(11):2214-2225.https://doi.org/ 10.1002/ptr.6158

21. Hu B, Yan W, Wang M, Cui X, Hu Y, Chen Q, Zhang Y, Qi X, Jiang J: Huaier polysaccharide inhibits the stem-like characteristics of ERalpha-36(high) triple negative breast cancer cells via inactivation of the ERalpha-36 signaling pathway. Int J Biol Sci 2019, 15(7):1358-1367.https://doi.org/ 10.7150/ijbs.27360

22. Shi L DB, Li Z, Lu Y, Ouyang T, Li J, Wang T, Fan Z, Fan T, Lin B, Wang Z, Xie Y. : Expression of ER- $\alpha 36$, a novel variant of estrogen receptor \{alpha\}, and resistance to tamoxifen treatment in breast cancer. Journal of clinical oncology : official journal of the American Society of Clinical Oncology 2009, 27(21):3423-3429.https://doi.org/ 10.1200/JCO.2008.17.2254

23. Zhu L, Zou J, Zhao Y, Jiang X, Wang Y, Wang X, Chen B: ER- $\alpha 36$ mediates cisplatin resistance in breast cancer cells through EGFR/HER-2/ERK signaling pathway. Journal of Experimental Clinical Cancer Research 2018, 37(1):123. https://doi.org/ 10.1186/s13046-018-0798-z

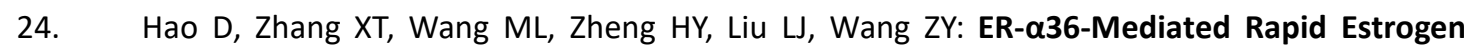
Signaling Positively Regulates ER-Positive Breast Cancer Stem/Progenitor Cells. PloS one 2014, 9(2):e88034. https://doi.org/ 10.1371/journal.pone.0088034

25. Zhang XT, Kang LG, Ding L, Vranic S, Gatalica Z, Wang ZY: A positive feedback loop of ER- $\alpha$ 36/EGFR promotes malignant growth of ER-negative breast cancer cells. Oncogene 2010, 30(7):770-780.https://doi.org/ 10.1038/onc.2010.458

26. Guo M WM, Deng $H$, Zhang X, Wang ZY. : A novel anticancer agent Broussoflavonol B downregulates estrogen receptor (ER)- $\alpha 36$ expression and inhibits growth of ER-negative breast cancer MDA-MB-231 cells. European Journal of Pharmacology 2013, 714(1-3):56-64. https://doi.org/ 10.1016/j.ejphar.2013.05.047

27. Zhang J LG, Li Z, Yu X, Zheng Y, Jin K, Wang H, Gong Y, Sun X, Teng X, Cao J, Teng L.: Estrogen-independent effects of ER- $\alpha 36$ in ER-negative breast cancer Steroids 2012, 77(06):666-673.https://doi.org/ 10.1016/j.steroids.2012.02.013

28. Wang X, Zheng N, Dong J, Wang X, Liu L, Huang J: Estrogen receptor-alpha36 is involved in icaritin induced growth inhibition of triple-negative breast cancer cells. J Steroid Biochem Mol Biol 2017, 171:318-327.https://doi.org/ 10.1016/j.jsbmb.2017.05.009

29. Pan C, Hu Y, Li J, Wang Z, Huang J, Zhang S, Ding L: Estrogen receptor-alpha36 is involved in 
pterostilbene-induced apoptosis and anti-proliferation in in vitro and in vivo breast cancer. PLoS One 2014, 9(8):e104459. https://doi.org/ 10.1371/journal.pone.0104459

30. Huang L, Li A, Liao $G$, Yang $F$, Yang J, Chen $X$, Jiang $X$ : Curcumol triggers apoptosis of $p 53$ mutant triple-negative human breast cancer MDA-MB 231 cells via activation of $p 73$ and PUMA. Oncol Lett 2017, 14(1):1080-1088.https://doi.org/ 10.3892/ol.2017.6273

31. Berger CM GX, Bouvet P. The roles of nucleolin subcellular localization in cancer. Biochimie 2015, 113:78-85. https://doi.org/ 10.1016/j.biochi.2015.03.023

32. Guan X, Yu D, HuangFu M, Huang Z, Dou T, Liu Y, Zhou L, Li X, Wang L, Liu H et al: Curcumol inhibits EBV-positive Nasopharyngeal carcinoma migration and invasion by targeting nucleolin. Biochem Pharmacol 2021, 192:114742. https://doi.org/10.1016/j.bcp. 2021.114742

33. Brignole C BV, Fonseca NA, Del Zotto G, Bruno S, Cruz AF, Malaguti F, Carlini B, Morandi F, Calarco E, Perri P, Moura V, Emionite L, Cilli M, De Leonardis F, Tondo A, Amoroso L, Conte M, Garaventa A, Sementa AR, Corrias MV, Ponzoni M, Moreira JN: Cell surface Nucleolin represents a novel cellular target for neuroblastoma therapy. J Exp Clin Cancer Res 2021, 40(1):180. https://doi.org/ 10.1186/s13046-021-01993-9

34. Soltysik K, Czekaj P: Membrane estrogen receptors - is it an alternative way of estrogen action? Journal of Physiology Pharmacology An Official Journal of the Polish Physiological Society 2013, 64(2):129.

35. Miricescu D, Totan A, Stanescu-Spinu II, Badoiu SC, Greabu M.PI3K/AKT/mTOR Signaling Pathway in Breast Cancer: From Molecular Landscape to Clinical Aspects. International journal of molecular sciences 2020, 22(1):173. https://doi.org/ 10.3390/ijms22010173

36. Verret B, Cortes J, Bachelot T, Andre F, Arnedos M: Efficacy of PI3K inhibitors in advanced breast cancer. Annals of Oncology 2019, 30(10):x12-x20.https://doi.org/ 10.1093/annonc

37. Zeng C, Fan D, Xu Y, Li X, Yuan J, Yang Q, Zhou X, Lu J, Zhang C, Han J et al: Curcumol enhances the sensitivity of doxorubicin in triple-negative breast cancer via regulating the miR-181b-2-3p-ABCC3 axis. Biochem Pharmacol 2020, 174:113795. https://doi.org/10.1016/ j.bcp.2020.113795

Statements and Declarations

Funding: This work was supported by the National Natural Science Foundation of China (grant\# 81760443, 81760663, 82160768 and 82002822), the Project of Guangxi Special Fund Project for Innovation-Driven Development (grant\# GuikeAA19254025), Guangxi Science and Technology and Talents Special Project (grant no. 2019AC19009), Guangxi Natural Science Foundation (grant\# Guike ZD20302006). MCF-7 TAM cells, ERa36 antibody and ERa36 plasmids were provided by professor Zhaoyi Wang (Creighton University Medical School).

Competing Interests: The authors declare no conflict of interest.

Author Contributions: Luwei Zhou performed the cell viability, Western blot analyses and wrote the manuscript. Juan Wang performed the Western blot analyses, review the manuscript and designed the experiments. Xiaojuan Li and Meng Jie Huang Fu performed flow cytometry analysis and Western blot 
analyses. Tong Dou and Yisa Liu preformed Western blot and animal experiments. Xiao Guan analyzed the data, Guoxiang Liu and Meng jie Han preformed Immunofluorescence assay. The experiments were designed by Xu Chen. All authors have read and agreed to the published version of the manuscript.

Ethics approval: Ethical approval for the use of animals was obtained prior to the start of this study from the Institutional Animal Care and Use Committee of Guilin Medical University (Guilin, China)

Consent to participate: Not applicable.

Consent to publish: Not applicable.

Figure legend

Fig 1 Curcumol inhibits breast cancer cells proliferation (a)Cell viability of different concentrations of TAM on breast cancer MCF-7 and MCF-7 TAM-R cells were detected by MTT assay at 24,48,72 h. (b)Cell colony forming of curcumol on MCF-7、MDA-MB-231、MCF-7 TAM-R cells were assessed by colony formation assay. (c) Cell viability of different concentrations of curcumol on breast cancer MCF-7、 MDA-MB-231、 MCF-7 TAM-R cells was detected by MTT assay at 24, 48 and $72 \mathrm{~h}$. And MCF 10A's cell viability was examined by MTT assay after treated with curcumol for $72 \mathrm{~h} .{ }^{*} P<0.05$, ${ }^{* *} P<0.01$ vs. Control group, ${ }^{\# \#} P<0.01,{ }^{\#} P<0.05$ vs. 24 h group.

Fig 2 Curcumol induced cells cycle arrest Cell cycle distribution was detected by flow cytometry following $48 \mathrm{~h}$ treatment with curcumol, the expression levels of cell cycle related-proteins CDK6、 Cyclin D1、CDK2 were analyzed by western blotting in MCF-7(a),MDA-MB-231(b) and MCF-7 TAM-R(c). Data are presented as means $\pm \mathrm{SD}(\mathrm{n}=3),{ }^{*} P<0.05,{ }^{* *} P<0.01$ vs. Control group. 
Fig 3 Curcumol inhibits the growth of breast cancer cells by regulating the PI3K/AKT pathway The protein expression of P110, P85, P-AKT, AKT were analyzed by western blotting in MCF-7 (a), MDA-MB-231(b), MCF-7 TAM-R(c). Data are presented as means $\pm \mathrm{SD}(\mathrm{n}=3),{ }^{*} P<0.05,{ }^{* *} P<0.01$ vs. Control group.

Fig 4 Curcumol inhibited the expression of ER $\alpha 36$ is related with its protein target NCL The protein expression of NCL and ER $\alpha 36$ were analyzed by western blotting in MCF-7(a), MDA-MB-231(b), MCF-7 TAM-R(c). (d) different expression of NCL between normal and breast cancer, the dataset from an internet analysis tool connected the database form The Cancer Genome Atlas (TCGA)(https://www.xiantao.love/products).(e) Immune co-precipitation between NCL and ER $\alpha 36$. (f) Dual Immunofluorescence staining for the co-localization of NCL and ER $\alpha 36$. Data are presented as means $\pm \mathrm{SD}(\mathrm{n}=3),{ }^{*} P<0.05,{ }^{* *} P<0.01$ vs. Control group.

Fig 5 Si-RNA for NCL reduced the regulation of curcumol on PI3K/AKT and reduced cycle arrest (a) MDA-MB-231cells were transfected with NCL siRNA and negative control siRNA(siNC) for $48 \mathrm{~h}$. The cells were identified by western blotting. (b) The expression of NCL and ER $\alpha 36$ were detected in NCL siRNA MDA-MB-231 cells with or without curcumol treatments. (c) Flow cytometry histograms indicated the cell cycle distribution patterns of MDA-MB-231 cells and NCL siRNA MDA-MB-231 cells with or without curcumol treatments. (d) The expression of P110, P85, P-AKT, AKT and cell cycle associated factors Cyclin D1, CDK6, PCNA and PARP-1 were detected by western blotting. Data are presented as means $\pm \mathrm{SD}(\mathrm{n}=3), * P<0.05, * * P<0.01$ vs. Control group.

Fig 6 ERa36 overexpression attenuated the inhibitory effect of curcumol (a) MCF-7 ER $336-L V$ cell line was identified by western blotting. (b) The expression of NCL and ER $\alpha 36$ were detected in MCF-7 cells and MCF-7 ERa36-LV cells with or without curcumol treatments. (c) Flow cytometry histograms showed the cell cycle distribution patterns of MCF-7 cells and MCF-7 ER $\alpha 36-\mathrm{LV}$ cells with or without curcumol treatments. (d)The expression of PI3K/AKT signaling pathway key factors and cell cycle associated factors were detected by western blotting. Data are presented as means \pm SD $(\mathrm{n}=3),{ }^{*} P<0.05,{ }^{*} P<0.01$ compared with MCF-7, ${ }^{\#} P<0.01,{ }^{\#} P<0.05$ vs. MCF-7 ER $\alpha 36$ group. 
Fig 7 Curcumol inhibition on tumor growth was reversed by ERa36 in vivo (a and b) Images of xenograft tumors demonstrated that MCF-7 ERa36-LV markedly increased tumor growth in vivo. Curcumol treatment significantly decreased the size of tumors in MCF-7 NC and MCF-7 ER $\alpha 36-\mathrm{LV}$ group in vivo. (c) Statistics of tumor sizes in different groups. (d) The body weight of nude mice were recorded very 4 days. (e) The expression proteins were detected by western blotting. The intensity of bands was quantified by Image J. Data are presented as means $\pm \mathrm{SD}(\mathrm{n}=3),{ }^{*} P<0.05, * * P<0.01$ compared with MCF-7 NC, ${ }^{\# \#} P<0.01,{ }^{\#} P<0.05$ compared with MCF-7 ER $\alpha 36-L V$ group.

Fig 8 Schematic representation of the action mechanisms of curcumol 


\section{Figures}

\section{Figure 1}

Curcumol inhibits breast cancer cells proliferation (a)Cell viability of different concentrations of TAM on breast cancer MCF-7 and MCF-7 TAM-R cells were detected by MTT assay at 24,48,72 h. (b)Cell colony forming of curcumol on MCF-7DMDA-MB-231DMCF-7 TAM-R cells were assessed by colony formation assay. (c) Cell viability of different concentrations of curcumol on breast cancer MCF-7\MDA-MB-231D MCF-7 TAM-R cells was detected by MTT assay at 24, 48 and $72 \mathrm{~h}$. And MCF $10 A^{\prime}$ s cell viability was examined by MTT assay after treated with curcumol for $72 \mathrm{~h} .{ }^{*} \mathrm{P}<0.05,{ }^{*} \mathrm{P}<0.01$ vs. Control group, $\# \# P<0.01, \# P<0.05$ vs. 
a

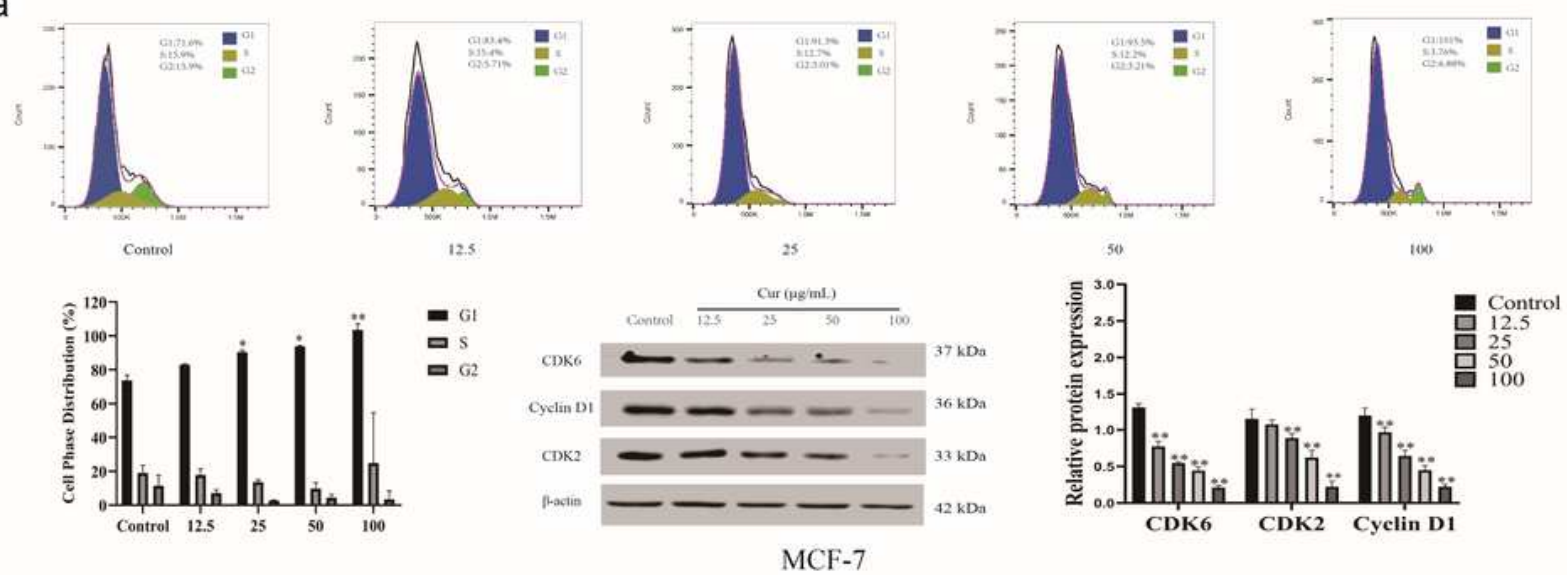

b

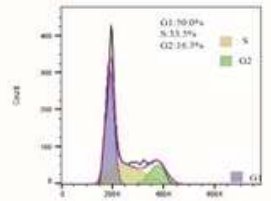

Control

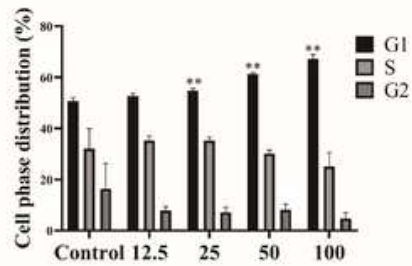

C

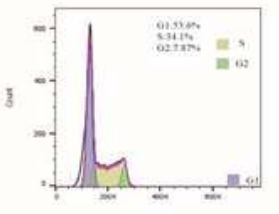

12.5

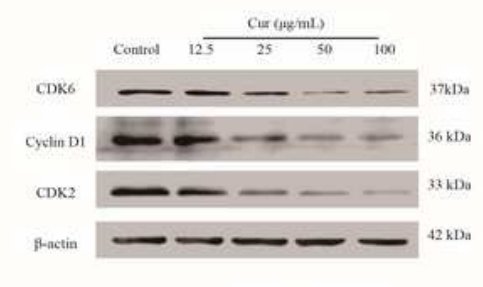

MDA-MB-231
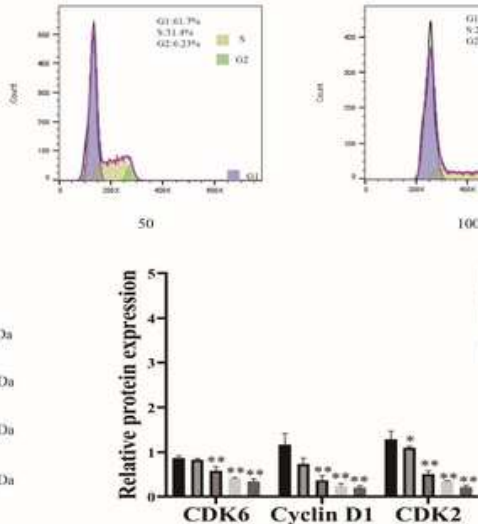

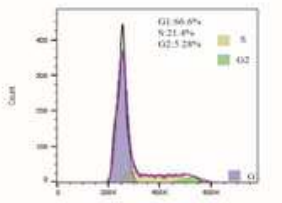

100

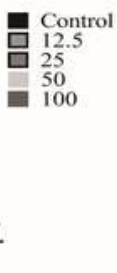

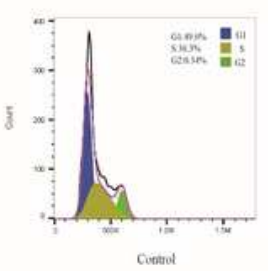
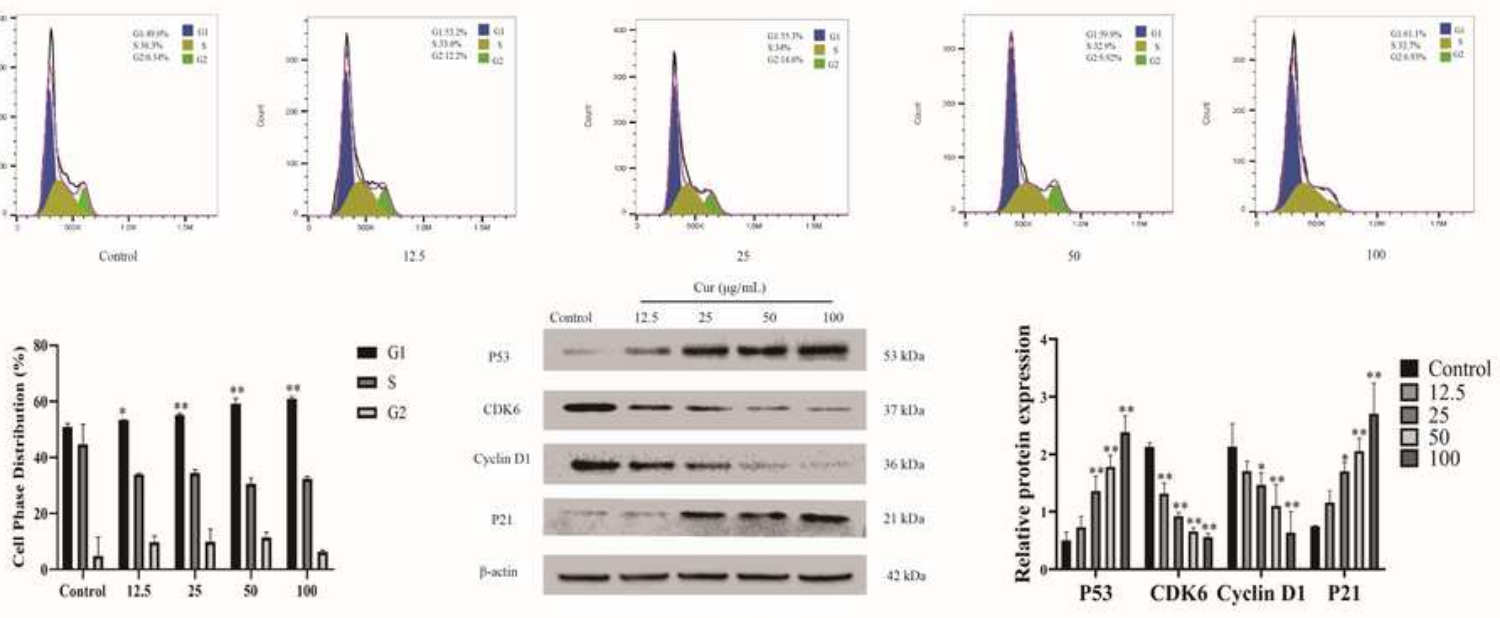

MCF-7 TAM-R

Figure 2

Curcumol induced cells cycle arrest Cell cycle distribution was detected by flow cytometry following $48 \mathrm{~h}$ treatment with curcumol囚the expression levels of cell cycle related-proteins CDK6, Cyclin D1DCDK2 were analyzed by western blotting in MCF-7(a),MDA-MB-231(b) and MCF-7 TAM-R(c). Data are presented as means $\pm S D(n=3),{ }^{*} P<0.05,{ }^{*} P<0.01$ vs. Control group. 
a
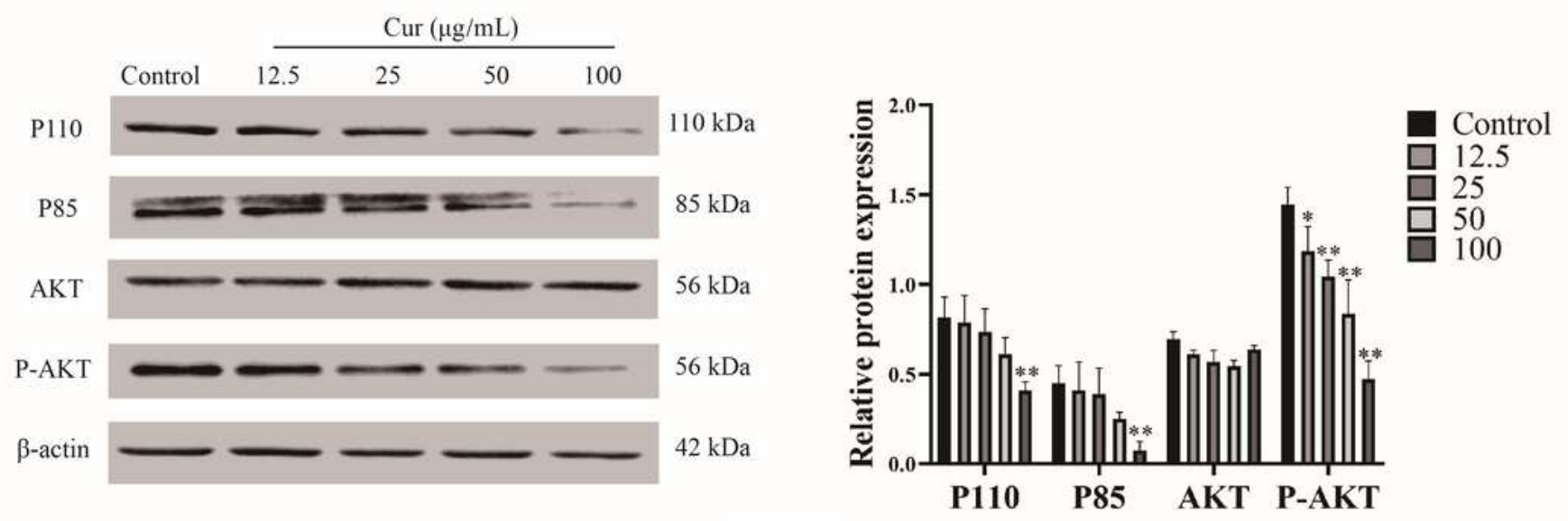

$\mathrm{b}$

MCF-7
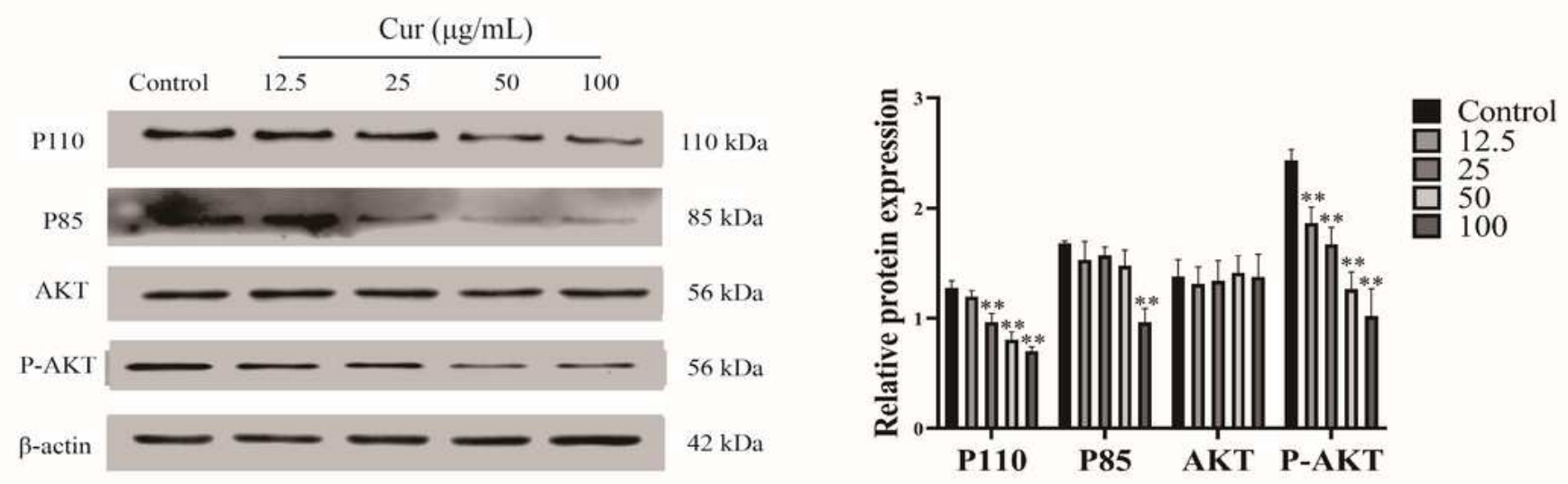

c

MDA-MB-231
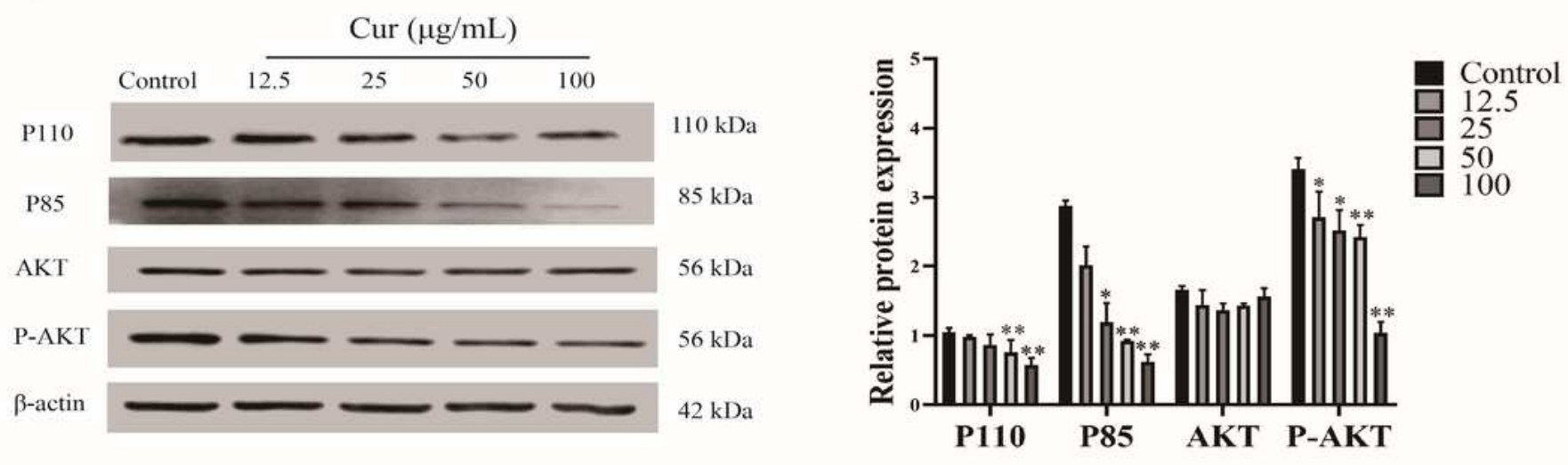

MCF-7 TAM-R

\section{Figure 3}

Curcumol inhibits the growth of breast cancer cells by regulating the PI3K/AKT pathway The protein expression of P110, P85, P-AKT, AKT were analyzed by western blotting in MCF-7 (a), MDA-MB-231(b), MCF-7 TAM-R(c). Data are presented as means $\pm S D(n=3),{ }^{*} P<0.05,{ }^{*} P<0.01$ vs. Control group. 
a

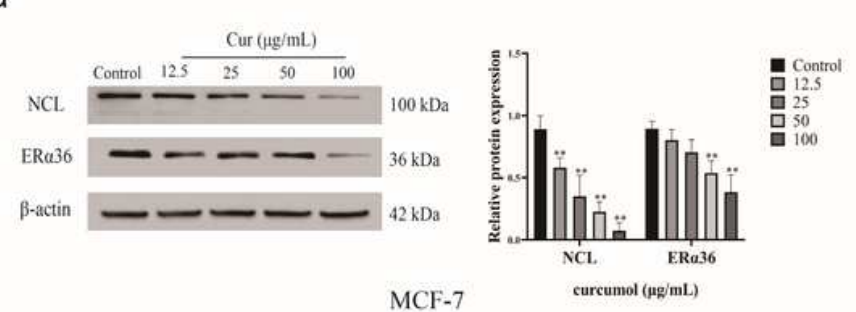

b

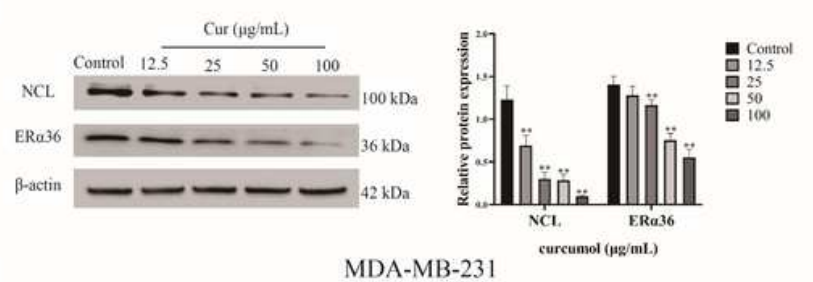

C

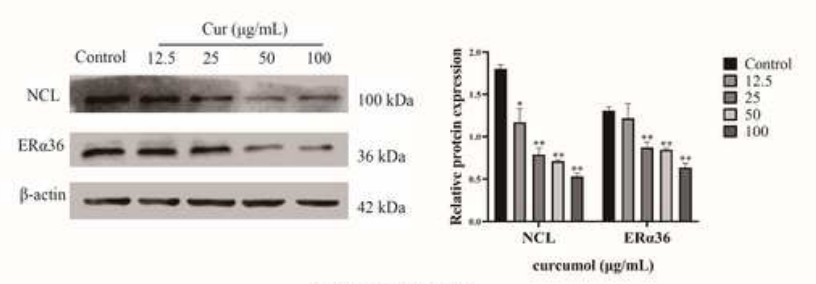

MCF-7 TAM-R d

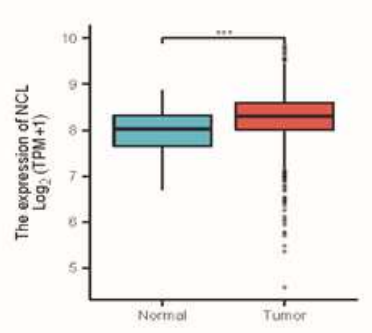

113

f
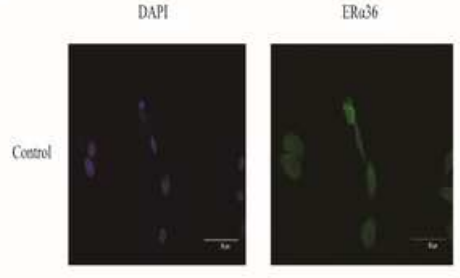

Cur

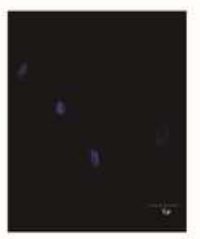

ERa36
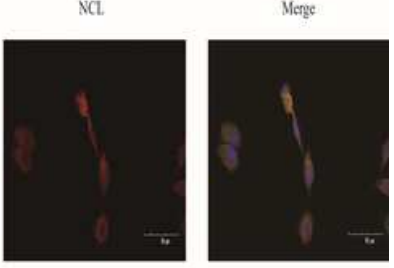

e

IP Input $\lg G \quad$ Flag
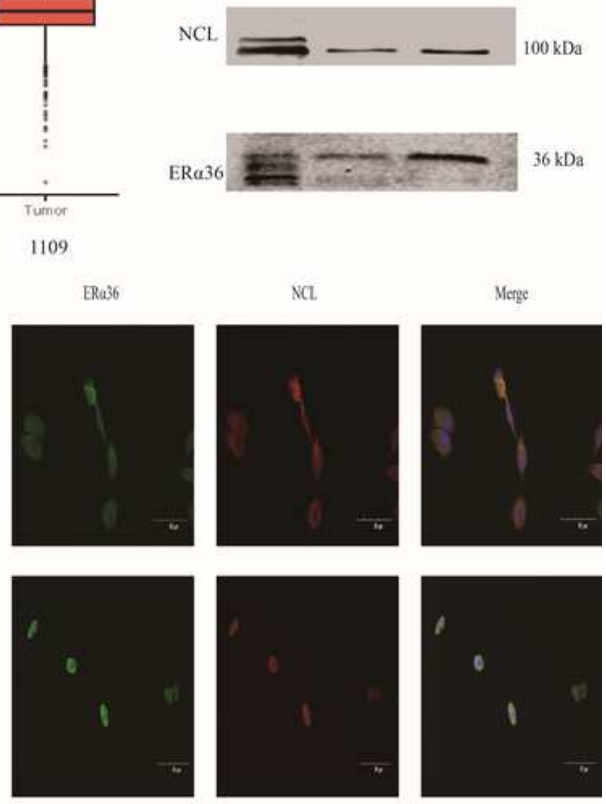

MCF-7 TAM-R

\section{Figure 4}

Curcumol inhibited the expression of ERa36 is related with its protein target NCL The protein expression of NCL and ERa36 were analyzed by western blotting in MCF-7(a), MDA-MB-231(b), MCF-7 TAM-R(c). (d) different expression of NCL between normal and breast cancer, the dataset from an internet analysis tool connected the database form The Cancer Genome Atlas (TCGA)(https://www.xiantao.love/products).(e) Immune co-precipitation between NCL and ERa36. (f) Dual Immunofluorescence staining for the colocalization of NCL and ERa36. Data are presented as means $\pm S D(n=3),{ }^{*}<0.05, * \star P<0.01$ vs. Control group 
a
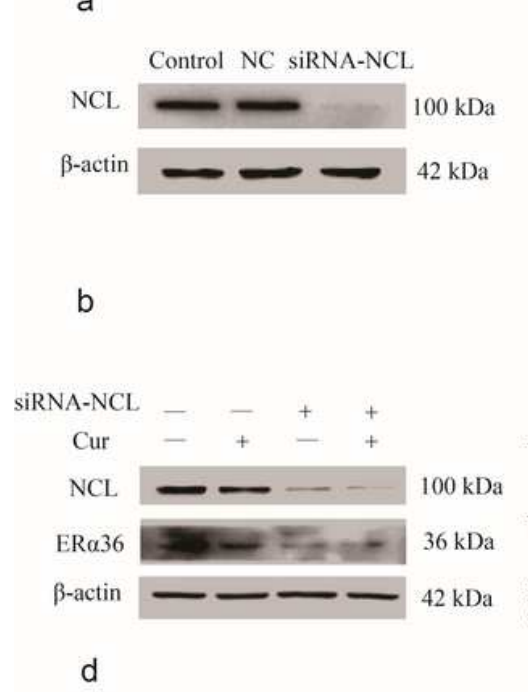

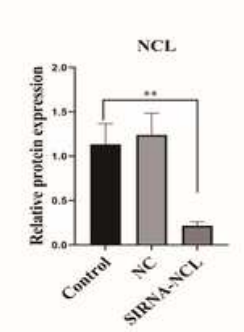

C
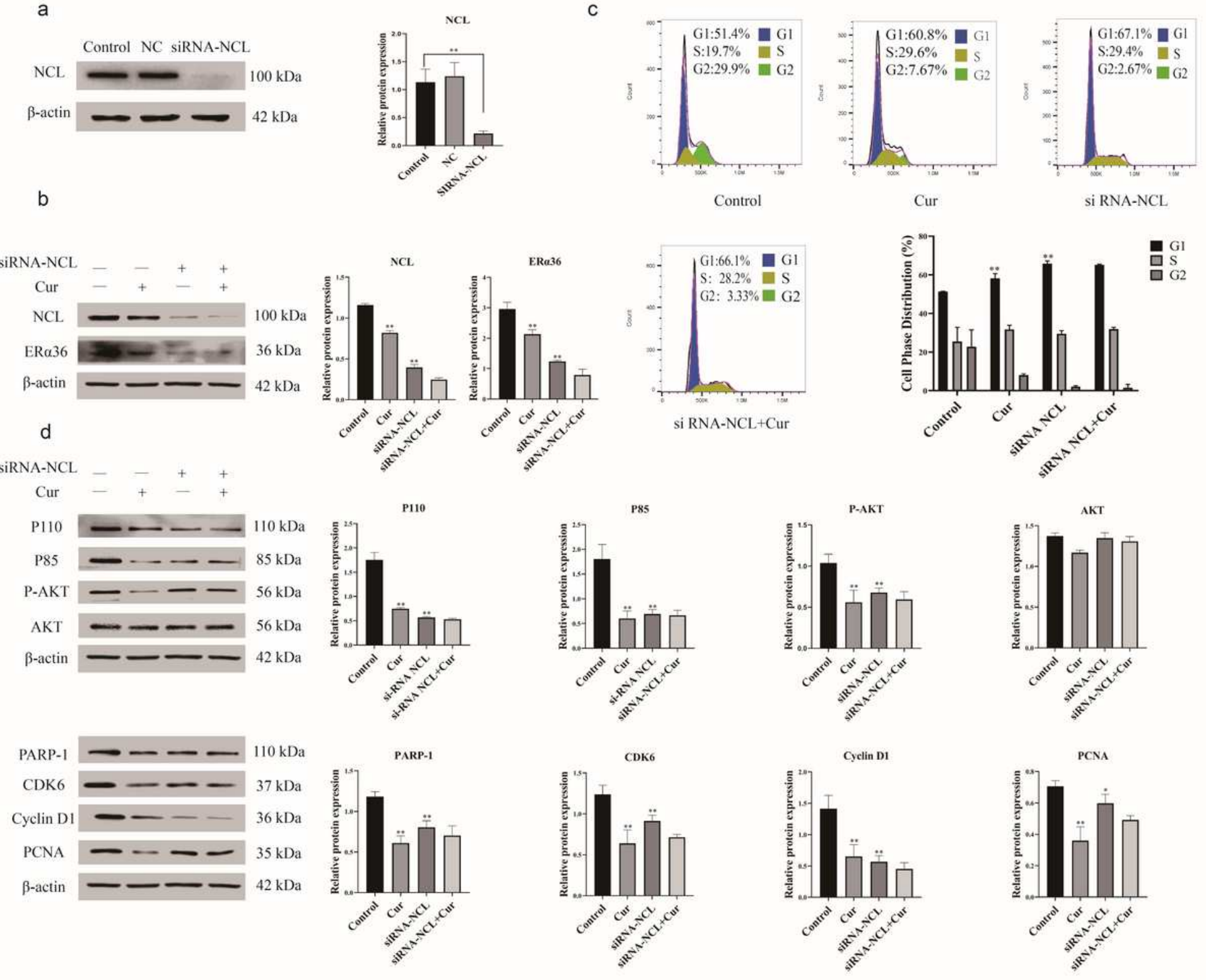

\section{Figure 5}

Si-RNA for NCL reduced the regulation of curcumol on PI3K / AKT and reduced cycle arrest (a) MDA-MB231cells were transfected with NCL siRNA and negative control siRNA(siNC) for $48 \mathrm{~h}$. The cells were identified by western blotting. (b) The expression of NCL and ERa36 were detected in NCL siRNA MDAMB-231 cells with or without curcumol treatments. (c) Flow cytometry histograms indicated the cell cycle distribution patterns of MDA-MB-231 cells and NCL siRNA MDA-MB-231 cells with or without curcumol treatments. (d) The expression of P110, P85, P-AKT, AKT and cell cycle associated factors Cyclin D1, CDK6, PCNA and PARP-1 were detected by western blotting. Data are presented as means $\pm S D(n=3)$, *P $<0.05,{ }^{*} \mathrm{P}<0.01$ vs. Control group. 
a

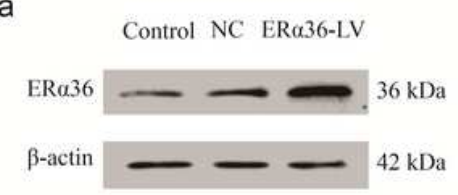

b
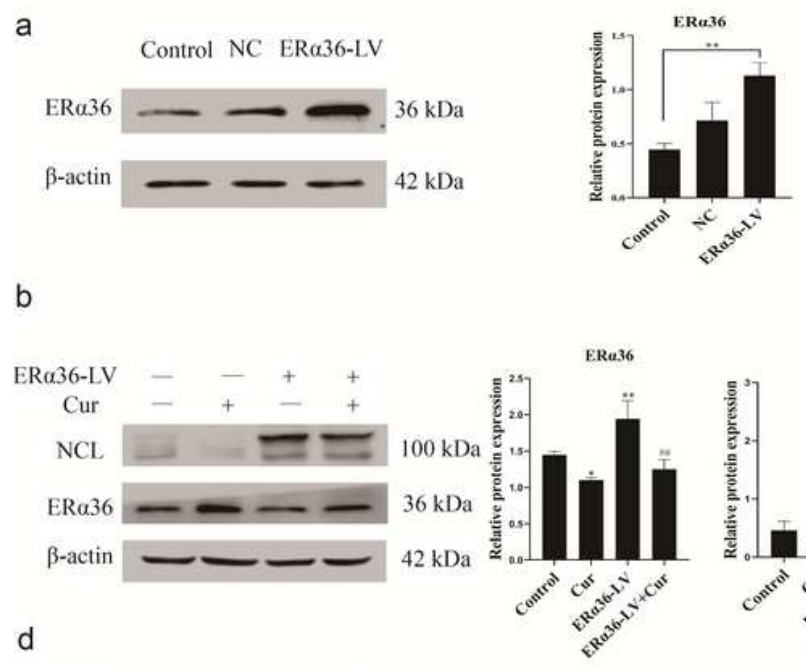

$\underset{\mathrm{Cur}}{\mathrm{ER} \alpha 36-\mathrm{LV}}-\underset{+}{+}+$

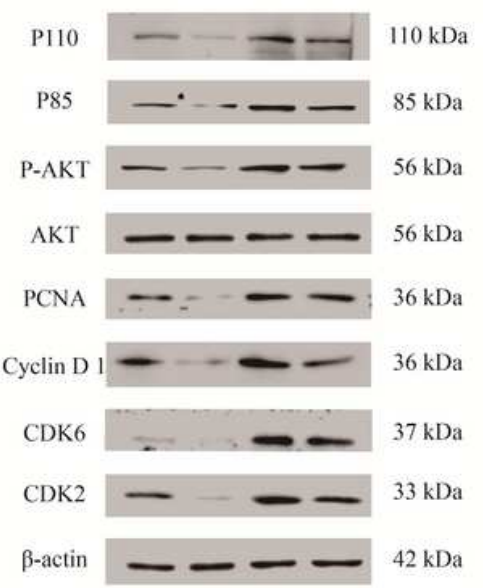

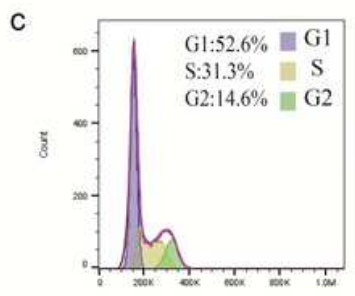

Control

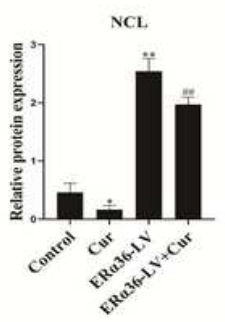

P110
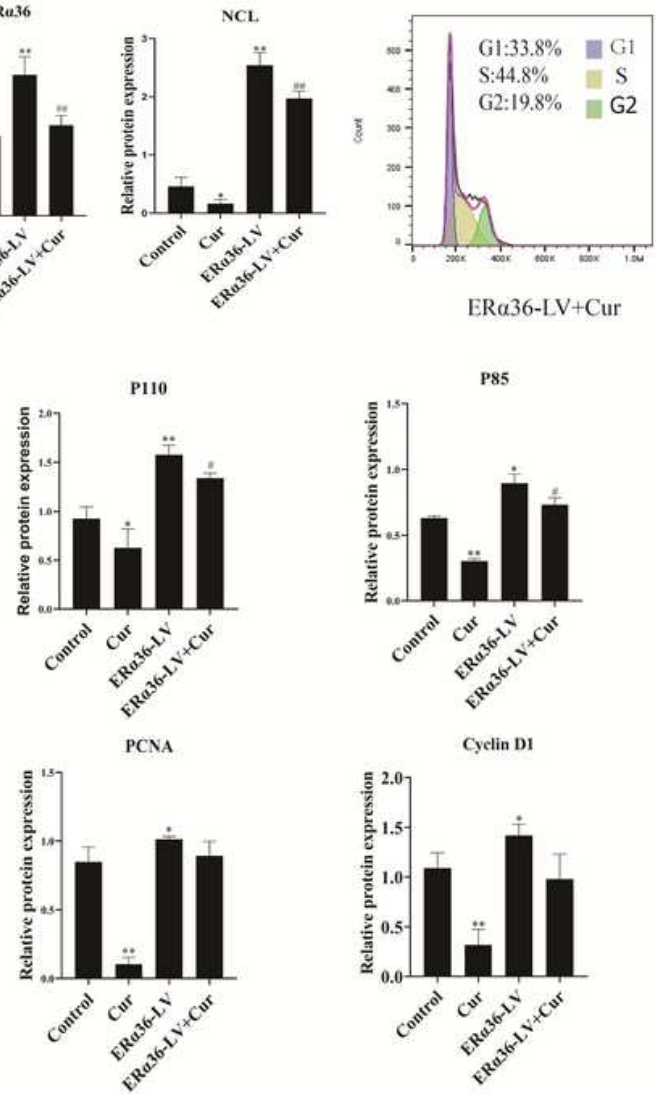

ERa36-LV+Cur

P85

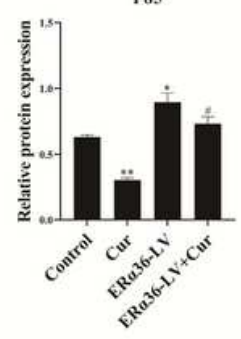

Cyelin DI

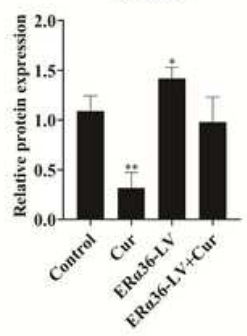

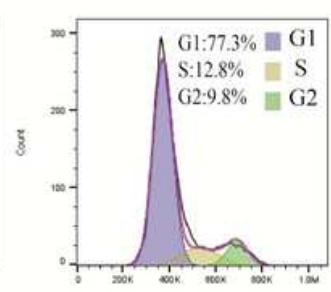

Cur

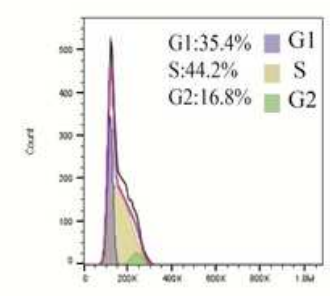

ERa36-LV

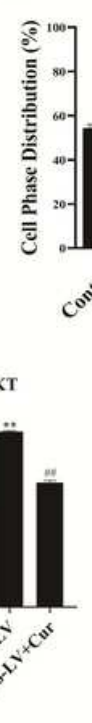

CDK6

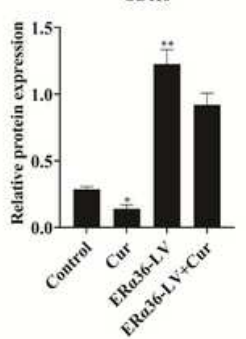

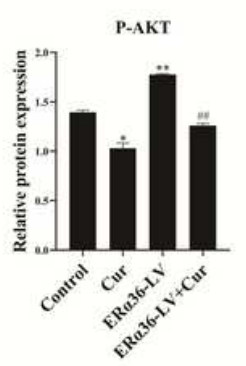

믐 $\mathrm{G} 1$
$\mathrm{~S}_{\mathrm{G} 2}$

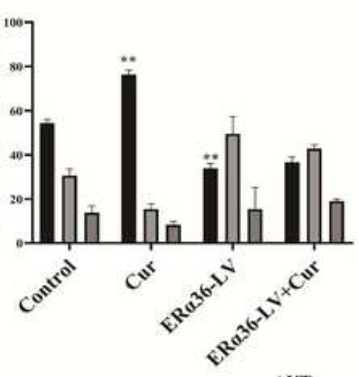

AKT

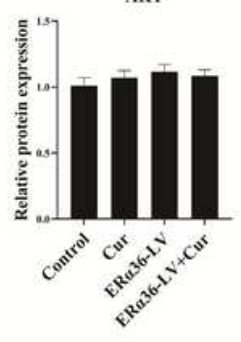

CDK2

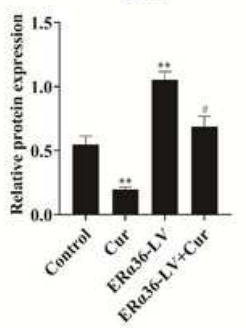

Figure 6

ERa36 overexpression attenuated the inhibitory effect of curcumol (a) MCF-7 ERa36-LV cell line was identified by western blotting. (b) The expression of NCL and ERa36 were detected in MCF-7 cells and MCF-7 ERa36-LV cells with or without curcumol treatments. (c) Flow cytometry histograms showed the cell cycle distribution patterns of MCF-7 cells and MCF-7 ERa36-LV cells with or without curcumol treatments. (d)The expression of PI3K/AKT signaling pathway key factors and cell cycle associated factors were detected by western blotting. Data are presented as means $\pm S D(n=3),{ }^{\star} P<0.05, \star \star P<0.01$ compared with MCF-7, \#\#P<0.01, \#P<0.05 vs. MCF-7 ERa36 group. 
a

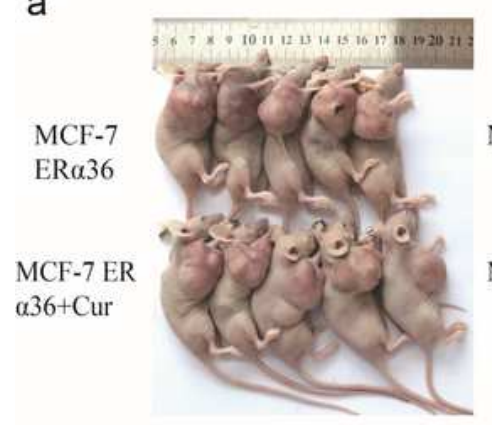

C

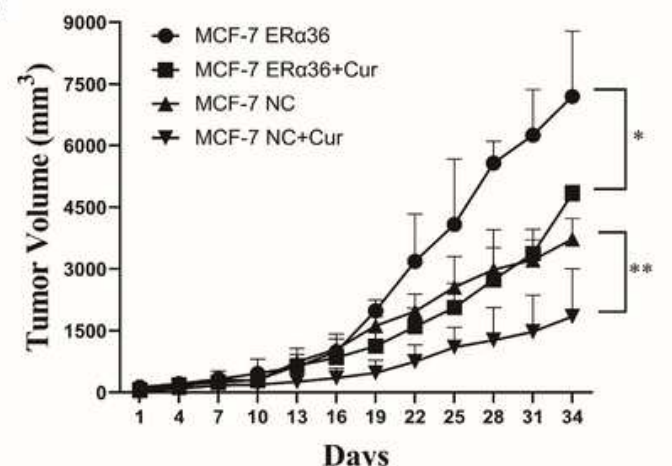

e

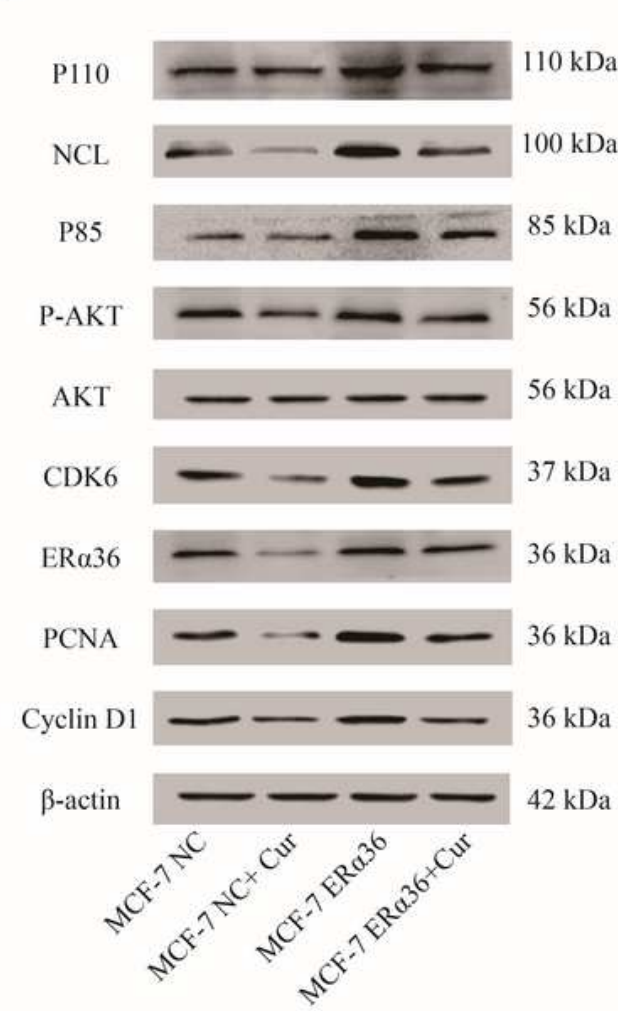

b
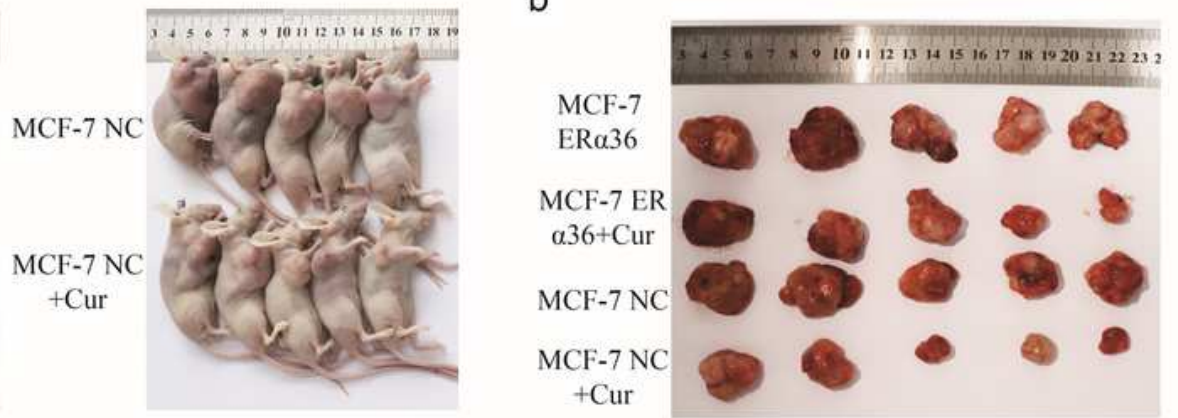

d

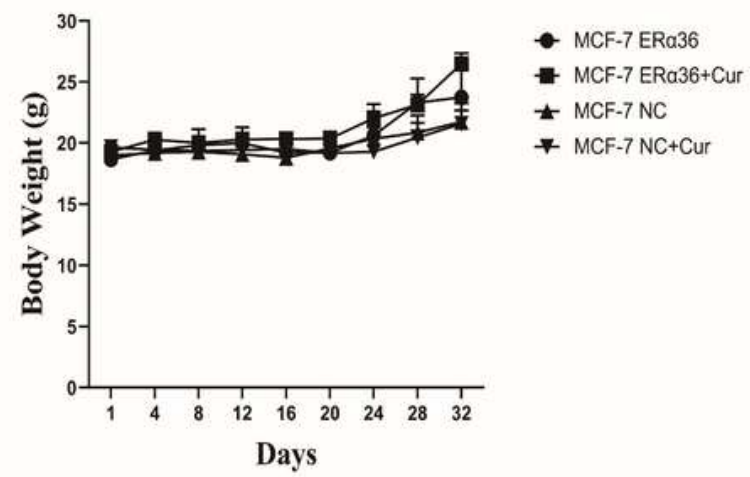

f
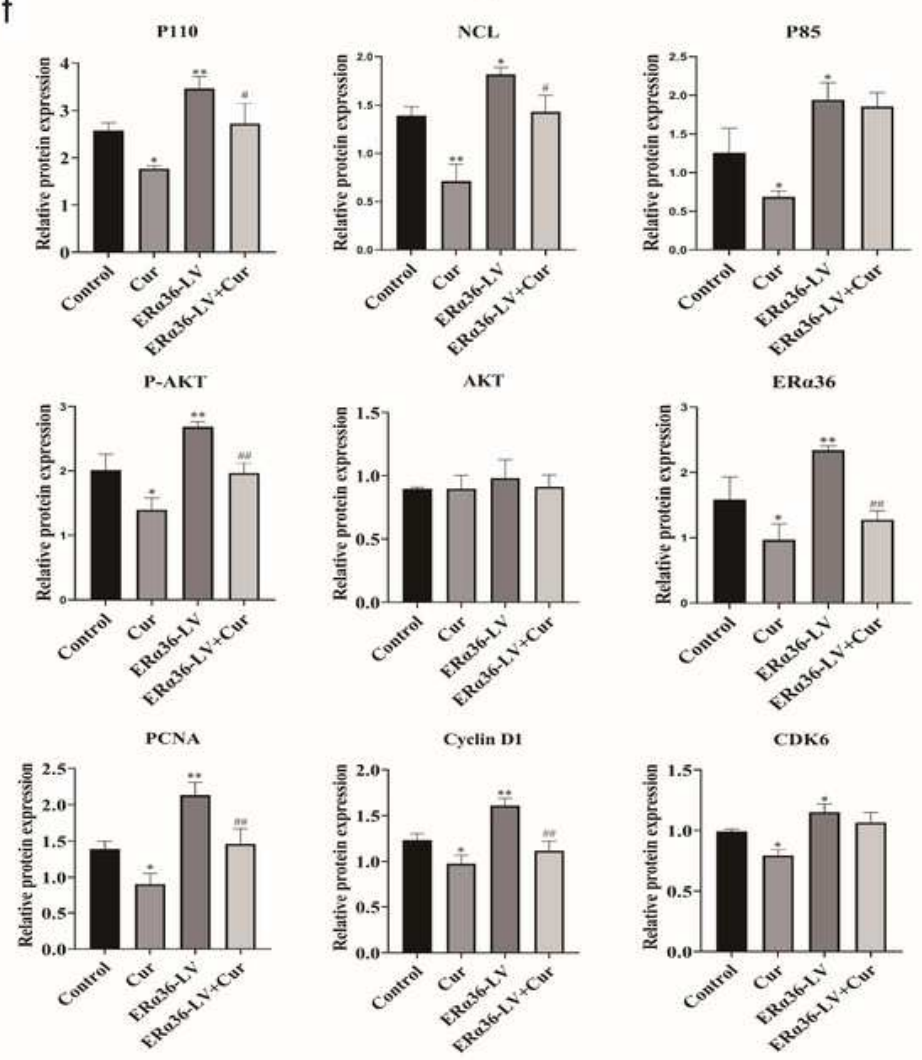

\section{Figure 7}

Curcumol inhibition on tumor growth was reversed by ERa36 in vivo (a and b) Images of xenograft tumors demonstrated that MCF-7 ERa36-LV markedly increased tumor growth in vivo. Curcumol treatment significantly decreased the size of tumors in MCF-7 NC and MCF-7 ERa36-LV group in vivo. (c) Statistics of tumor sizes in different groups. (d) The body weight of nude mice were recorded very 4 days. (e) The expression proteins were detected by western blotting. The intensity of bands was quantified by 
Image J. Data are presented as means $\pm S D(n=3),{ }^{*} P<0.05$, $* * P<0.01$ compared with MCF-7 NC, \#\#P< $0.01, \# P<0.05$ compared with MCF-7 ERa36-LV group

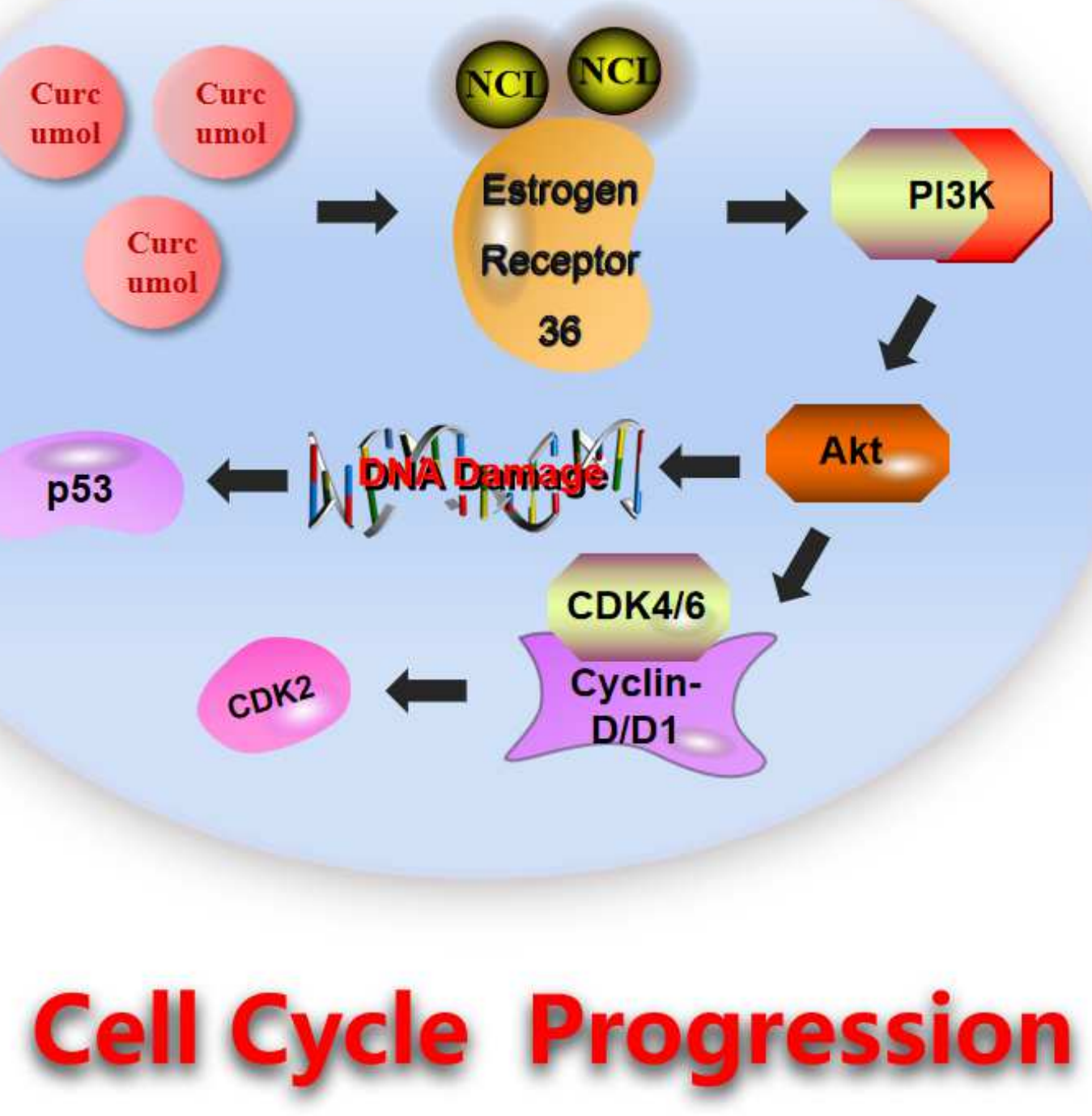

Figure 8

Schematic representation of the action mechanisms of curcumol.

\section{Supplementary Files}

This is a list of supplementary files associated with this preprint. Click to download.

- appendix.doc 